\title{
PANAMA PAPERS DAN FENOMENA PENYELUNDUPAN PAJAK SERTA IMPLIKASINYA TERHADAP PENERIMAAN PAJAK INDONESIA
}

\author{
Chairil Anwar Pohan \\ Institut Ilmu Sosial dan Manajemen Stiami \\ anwar.phn@gmail.com
}

\begin{abstract}
Abstrak. Kebocoran 11,5 juta file dokumen finansial terbesar yang belum pernah terjadi sebelumnya dari database Mossack Fonseca yang merupakan firma hukum terbesar keempat yang berbasis di Panama yang mengurusi bisnis yang bebas atau tidak dikenakan pajak. File-file ini berisi tentang bagaimana orang-orang terkenal dan kaya raya menyembunyikan kekayaannya dari kewajiban membayar pajak. Secara total, kebocoran ini berisi informasi tentang lebih dari 214 ribu entitas bebas pajak yang terhubung ke orang-orang kaya di lebih dari 200 negara (termasuk cukup banyak dari Indonesia yang melakukan penggelapan pajak yang jumlahnya mencapai ribuan triliun, kurang lebih 899 orang dan perusahaan di Indonesia yang menjadi perusahaan off shore maupun menjadi pemegang saham dan direktur perusahaan off shore tersebut (tempo.co.id) disembunyikan di negara-negara surga pajak.
\end{abstract}

Kata Kunci : Panama Papers, Penyelundupan pajak, Penerimaan pajak

Abstract. Leakage of 11.5 million the biggest financial document file unprecedented from Mossack Fonseca database which is the fourth largest law firm based in Panama in charge of tax-free or tax-exempt business. These files contain about how famous people and rich hide their wealth from the obligation to pay taxes. In total, this leak contains information about more than 214 thousand tax-exempt entities connected to rich people in more than 200 countries (including quite a lot from Indonesia who evade taxes numbering in the thousands trillion, approximately 899 people and companies in Indonesia, which became the company off shore and became a shareholder and director of the off shore company (tempo.co.id) is hidden in tax haven countries.

Key Words : Panama Paper, Tax Evasion, Tax Revenue

Jutaan dokumen finansial dari sebuah firma hukum asal Panama Mossack Fonseca, bocor dan mengungkapkan bagaimana jejaring korupsi dan kejahatan pajak para pengusaha, kepala negara, agen rahasia, pesohor sampai buronan, serta orang-orang terkenal dan kaya raya menyembunyikan kekayaannya dari kewajiban membayar pajak. Sebagai contoh, Swiss adalah salah satu negara yang selama ini dikenal sebagai surga menyimpan uang. Para nasabah kakap-entah itu orang kaya atau koruptor berbondongbondong menyimpan uang mereka di perbankan. Pemerintah dan otoritas moneter Swiss melarang bank dan karyawannya membocorkan data nasabah. Bila aturan ini dilanggar, hukumannya amat berat. Selain Swiss, ada Liechtenstein. Negara mungil yang berada di Pegunungan Alpen ini menjadi tempat yang sangat menarik bagi para konglomerat menyimpan uang. Seperti halnya Swiss, sistem perbankan yang dianut di Liechtenstein sangat mengagungkan kerahasiaan data nasabah. Firma hukum Mossack Foncesa didirikan oleh laki-laki kelahiran Jerman bernama Juergen Mossack.

Bocornya data ini bermula ketika koalisi media internasional International Consortium of Investigative Journalism (ICIJ) dan surat kabar Jerman Sueddeutsche Zeitung 
menerima data dari seorang sumber anonim, lebih dari setahun yang lalu. Menurut ICIJ, data itu berupa e-mail spreadsheet keuangan, paspor, dan catatan-catatan perusahaan yang merinci bagaimana orang-orang kuat ini memanfaatkan bank, firma hukum, dan perusahaan-perusahaan kategori shell company untuk menyimpan aset mereka. Data itu membentang sekitar 40 tahun, dari 1977 hingga akhir 2015 (Tribujateng.com, 5 April 2016).

\section{Panama Papers dan Implikasi \\ Perpajakannya Ke Indonesia \\ Terkait dengan penentuan tarif pajak}

di suatu negara, Suzuki (2013: 1) menyimpulkan bahwa negara kecil di Asia, seperti Singapura, akan menerapkan tarif pajak yang lebih rendah untuk mendorong modal asing masuk ke negara tersebut. Namun, negara yang memiliki pasar domestik yang luas, seperti Indonesia, menerapkan tarif pajak yang lebih tinggi karena adanya perbedaan tingkat elastisitas penerimaan pajak antara negara besar dengan negara kecil. Dalam hal ini, tarif pajak yang optimal adalah seperti yang diungkapkan oleh Saez (2001: 208), yaitu tarif pajak yang apabila dilakukan perubahan sekecil apapun terhadap tarif pajak tersebut tidak menimbulkan dampak negatif terhadap kemakmuran masyarakat (Jurnal BPPK, Vol. No. 1, 2014:14).

Akhir-akhir ini negara Indonesia diterpa berbagai persoalan perekonomian yang cukup pelik, perekonomian hanya tumbuh 4,9 persen pada kuartal pertama 2016 lebih rendah daripada asumsi 5,3 persen yang tercantum dalam APBN 2016. Utang negara semakin meningkat, Koefisien GINI yang mengukur ketimpangan distribusi pendapatan/ mencerminkan tingkat kemiskinan semakin tinggi, tingkat pengangguran juga semakin tinggi. Karena tidak punya dana yang cukup terpaksa RAPBN 2016 diciutkan, penyesuaianpun terpaksa harus dilakukan dengan sederetan proyek-proyek pembangunan yang harus dipangkas anggarannya demi menyelamatkan program- program pembangunan bangsa yang sudah terlanjur digelar untuk mengejar kenaikan pertumbuhan ekonomi dan indikator-indikator kesejahteraan masyarakat yang terindeks seperti tingkat inflasi, pengangguran dan sebagainya, atau bila tidak dilakukan penyesuaian maka program-program kegiatan pembangunan bangsa tersebut bersifat kontraproduktif yang akan menjerat negara ini pada krisis keuangan dan ekonomi yang berkesinambungan, seperti pepatah mengatakan "besar pasak dari tiang" dan kitapun akan terperangkap dalam lubang hutang yang semakin melebar. Tidak pelak lagi akar permasalahan atau penyebab utamanya adalah target pajak tidak terpenuhi yang implikasinya pada terjadinya ketidakkecukupan penerimaan negara untuk membiayai kegiatan penyelenggaraan pemerintahan. Tapi yang jelas asas kecukupan penerimaan negara menjadi terganggu, dan inilah yang menjadi pemicu utama kenapa pemerintah Indonesia dengat tekat yang sangat bulat mendeklarasikan pengesahan Undang-Undang Pengampunan Pajak yang sejak efektif berlaku sejak awal Juli 2016 sebagai pendamping dari Perangkat UndangUndang Perpajakan yang sudah dibuat terdahulu beserta ribuan banyak peraturan pelaksanaannya sebagai instrumen penegakan hukum perpajakan(law enforcement), dan tentu saja instumen ini sekaligus bisa menjadi salah satu penangkal terhadap "tax haven minded" dari para pelaku bisnis yang selama ini menyembunyikan dananya di tax haven countries agar mau pulang ke tanah air kita yang tercinta ini.

\section{Tax Haven dan Penyelundupan Pajak}

Larry Crumbley, Jack P. Friedman, dan Susan B. Andrers, dalam "Dictionary of Tax Terms" (1994: 297) mendefinisikan tax haven (dalam artian bebas) "Tax Haven adalah suatu jurisdiksi yang membolehkan transaksi berlangsung dalam kondisi yang sangat dirahasiakan yang melegalisir wajib pajak menghindari pajak. Beberapa negaranegara tax haven yang sudah terkenal adalah British Virgin Islands, Caymand Islands, Liechtenstein, Netherlands Antiles, and 
Chairil Anwar Pohan, Panama Papers Dan Fenomena Penyelundupan Pajak Serta Implikasinya...

Panama.". Azzara dalam Tax Heaven of The World, 2000 menyebutkan bahwa tax havens merupakan negara merdeka dengan pajak minimal atau tanpa pajak. Secara nomenklatur, tax havens merupakan tempat yang menawarkan lingkungan kegiatan usaha dengan bebas pajak atau dengan pajak minimal. (Gunadi, 2007 : 284). Azzara memberikan contoh seperti Caymand Islands, Bahama, Bermuda, British Virgin Islands, Liechtenstein, Netherlands Antiles, and Panama."

Pada saat pertemuan KTT pemerintahan G-20 di Excel Centre, Dockland, London, yang didukung oleh Kanselir Jerman Angela Merkel, mereka menginginkan agar pasar dapat diatur dengan regulasi yang jelas. Sasaran lainnya adalah negara surga pajak (tax haven) juga dikendalikan. Negara-negara tax haven itu yang umumnya produk buatan kolonialis Inggris seperti Singapura, Hongkong, dan 33 negara atau teritori lainnya yang juga menjadi tax haven. Negara tersebut dianggap sebagai pelindung para kapitalis pemangsa, lokasi penyimpanan uang haram, lokasi aksi-aksi spekulasi yang telah melahirkan fenomena kanibal di sektor keuangan (Kompas, 5April 2009).

Untuk mengatasi krisis keuangan global perlu reformasi regulasi dan peraturan dalam sistem keuangan, salah satunya soal pengaturan tax haven dengan kehadiran Financial Stability Board. G-20 juga sepakat mendesak sebuah upaya untuk standardisasi akuntansi, aturan mengenai hedge fund yang selama ini tidak mudah tersentuh dan aturan mengenai tax haven. Para pemimpin G-20 juga sepakat masalah kerahasiaan perbankan harus diakhiri dan tidak ada toleransi lagi bagi negara ataupun teritori pelindung para penghindar pajak dan kejahatan kerah putih lainnya(white collar crime). Dampak dari krisis finansial yang hebat membuat negaranegara maju menginginkan pajak yang dilarikan korporasi penghindar pajak (tax avoiders) dapat kembali menjadi hak negaranya.
Masalah kerahasiaan bank (bank secrecy) dianggap salah satu yang memperburuk krisis keuangan global karena tax haven yang menyembunyikan aset-aset global. Ada dugaan kuat bahwa tax haven countries ini memberikan tempat berlindung yang nyaman bagi para pejabat untuk menyembunyikan dana-dana ilegal hasil korupsi, ataupun pengusaha hitam yang melarikan dana dari kejaran aparat hukum di negerinya. Organisasi Kerja sama Ekonomi dan Pembangunan (OECD) telah mengumumkan kriteria negara-negara atau teritori sebagai surga pajak. Empat negara masuk dalam daftar hitam atau black, list karena tidak kooperatif, yaitu Filipina, Uruguay, Kosta Rika, dan Malaysia (Labuan). Mereka menolak menerapkan asas transparansi perbankan ataupun informasi mengenai pajak dalam skim exchange information.

OECD menyusun daftar negara atau teritori tax haven berdasarkan tiga kategori sebagai berikut: (1). negara yang siap melakukan pertukaran informasi atau telah mengimplementasikan standar perpajakan dan perbankan dengan baik (white list). (2). mereka siap untuk bertindak atau sudah berkomitmen, tetapi belum sepenuhnya mengimplementasikan standar perpajakan dan perbankan dengan baik (grey list). (3). negara atau teritori yang belum sepakat menerapkan asas transparansi atau belum mau berkomitmen (black list).

Surga pajak termasuk entitas politik yang menawarkan pengenaan pajak yang rendah dan pelindung bagi penghindar pajak. Surga pajak atau off-shore center menurut OECD Report on Harmful Tax Competition (1988) didefinisikan dalam empat kriteria. Dua kriteria surga pajak adalah pengenaan pajak yang rendah atau nihil dan memberikan kesempatan kepada nonresiden untuk menghindari pajak di negaranya dan melayani aktivitas ilegal.

Selain itu, surga pajak tidak melakukan pertukaran informasi perpajakan yang efektif berdasarkan UU atau praktik administratifnya dan tidak transparan dalam menjalankan kegiatannya. 
Pada umumnya beberapa negara memenuhi kebutuhan dana pembiayaan pemerintahannya dengan memungut pajak. Namun dalam rangka menarik para pengusaha untuk melakukan kegiatan usaha atau kegiatan ekonomi di negaranya, terdapat juga beberapa negara yang tidak memungut pajak atau memungut dalam jumlah minimal. Mereka mencukupi kebutuhan pembiayaan negaranya melalui imbalan (fee) pendirian usaha, imbalan pelaporan tahunan, lisensi industri, perbankan dan asuransi, dan bea meterai serta beberapa bea lainnya.

Tax haven countries dikenal sebagai tempat berlindung pengemplang pajak. Implikasi dari praktek tax haven ini adalah terjadinya pengalihan pajak ke negara tax haven dan/atau penggerusan pajak di negara lainnya (negara sumber). Di kawasan Asia saja Indonesia dikelilingi banyak negara yang menjadi tax heaven. Seperti Brunei Darussalam, Malaysia, Singapura, Filipina, Hong Kong, atau Makau yang mana negaranegara tersebut masuk dalam daftar negaranegara tax haven menurut daftar yang diterbitkan OECD (Organization for Economic Cooperation and Development). Dalam menghadapi masalah yang ditimbulkan oleh tax havens tersebut, OECD telah mengambil langkah-langkah penertiban. Bagi negara Indonesia, Implikasi penertiban tax havens tersebut akan membantu Indonesia dalam meningkatkan penerimaan pajak.

\section{Fenomena Tax Heaven}

Menurut Direktur Jenderal Pajak Darmin Nasution pada saat itu (Media Indonesia, 1 Mei 2009, bahwa banyak perusahaan di Indonesia terkait dengan negara-negara yang menjadi surga bagi penghindaran pajak (tax havens country). Jangan nilai bahwa itu hanya dilakukan oleh perusahaan atau orang asing. Perusahaanperusahaan kita semuanya pasti terkait dengan tax havens country. Juga konglomeratkonglomerat kita. Untuk mendeteksi praktik penghindaran pajak yang sifatnya sudah lintas negara, pihaknya mengusulkan penempatan intelijen ekonomi di berbagai negara yang memiliki keterkaitan ekonomi dengan Indonesia termasuk di tax havens country. Intelijen ekonomi itu ditempatkan di negaranegara yang investornya banyak ke Indonesia. Banyak sekali perusahaan kita yang dilihat struktur kepemilikan itu bercabang-cabang semua, dan selalu ada yang ditempatkan di tax havens country.

Praktek tax haven ini tampaknya sudah menjadi bagian dunia usaha dan bisnis serta sistem perpajakan. Para pengusaha di negara berkembang memanfaatkan tax haven countries untuk menyembunyikan atau melarikan pajak (tax flight) dan menempatkan tax haven countries sebagai negara-negara pusat financial tempat tujuan pelarian capital (capital flight). Menurut Sekretaris Jenderal OECD Jose Angel Gurria, jumlah uang yang disembunyikan oleh perseorangan dan korporasi di negara atau wilayah tax havens untuk menghindari pajak atau menghindar dari ketidakstabilan politik berkisar antara USD5-7 triliun (DannyDarussalam.com Tax Center, 15/4/09 ). Singapura masih menjadi negara tax haven favorit pengusaha nakal Indonesia. Menurut riset Meryll Lych sepertiga pengusaha kaya Singapura berasal dari Indonesia dengan kekayaan mencapai US\$68 miliar sampai US\$70 miliar. Hal itu karena kebijakan pajak di negara tersebut sangat ringan dengan kemudahan memperoleh hak residen (Media Indonesia, 1 Mei 2009).

\section{Karakteristik Negara Tax Haven}

Dengan mendekripsikan karakteristikkarateristik dari sebuah tax haven, maka kita bisa mengindikasikan bahwa suatu yurisdiksi bisa disebut tax haven atau bukan, bisa terlihat apakah yurisdiksi tersebut memiliki. Karakteristik tax haven menurut Organisation for Economic Co-operation and Development (OECD,1998), yakni: (1).Memiliki tarif pajak yang rendah atau tidak ada pajak sama sekali. (2).Tidak memiliki skema pertukaran informasi. Ini memungkinkan mereka yang memanfaatkan tax haven tidak terdeteksi oleh otoritas pajak.(3).Tidak adanya transparansi dalam proses legislasi, proses hukum, dan 
administrasi dalam yurisdiksi tersebut. (4).Tidak adanya persyaratan substansi ekonomi dalam pendirian perusahaan. Hal ini menyebabkan perusahaan didirikan untuk mendapatkan manfaat pajak saja, tanpa benar benar memiliki kegiatan bisnis.

Selain keempat kriteria tersebut, masih banyak lagi kriteria lain yang digunakan, misalnya: negara tersebut memiliki tata kelola pemerintahan yang baik, kemudahan dalam penggunaan special vehicles company, kemudahan dalam mendirikan perusahaan, longgarnya pengawasan, dan kemudahankemudahan pajak yang hanya tersedia bagi SPDN yurisdiksi itu saja (ring fencing). Banyaknya kriteria tersebut membuat banyak pula versi dari daftar tax haven itu sendiri. Namun, dari sekian banyak kriteria yang ada, agaknya definisi dari Palan, Murphy, dan Chavagneux (2010) dirasa paling tepat, yaitu: yurisdiksi yang secara khusus membuat peraturan untuk memudahkan transaksi yang dilakukan oleh non-residen dengan maksud untuk menghindari pajak atau regulasi, yang difasilitasi dengan cara memberikan kerahasian guna mengamankan pihak penerima manfaat dari transaksi tersebut (http://dannydarussalam.com/insights/panama -papers-perencanaan-pajak- penghin daranpajak-ataukah-penggelapan-pajak-2).

Untuk mengindikasikan suatu negara dikategorikan sebagai negara-negara tax haven adalah sebagai berikut: (1) Bentuk negaranya kecil, memiliki jaringan dan fasilitas komunikasi yang canggih (sophisticated), namun memiliki kemapanan ekonomi yang memungkinkan memberikan fasilitas kemudahan pajak. Negara ini mempromosikan keunggulan negaranya sebagai pusat keuangan (Financial Center) dan investasi. Untuk mendukung operasionalisasi perbankannya, biasanya negara tersebut mendapat perlindungan dari negara besar. Pemerintahnya mengetahui bahwa perusahaan-perusahaan investor asing yang terdaftar di negara tax haven hanya berfungsi sebagai reinvoicing center atau letter box company, biasanya tidak memiliki kegiatan usaha (active business). (2) menerapkan konsep low tax rates yang relatif lebih rendah dibandingkan negara lainnya, yang tujuannya semata untuk menarik investasi asing, memberikan daya tarik utama kemudahan pajak bagi investor asing dengan cara tidak memungut pajak, kalaupun ada maka tarif pajaknya sangat rendah bahkan 0 \%. (3) Sekuritas investasi dan kerahasiaan bank dijaga dengan sangat ketat, termasuk kerahasiaan korporat, finansil dan perdagangannya, dengan maksud menutupi penyembunyian transaksi banking, subjek dan objek pajak. Ketertarikan investor asing terutama pada tidak adanya keharusan pemerintah negara tax haven tersebut untuk mengumumkan kepada publik para pemilik perusahaan yang didirikan, ditambah lagi negara tax haven tersebut biasanya tidak transparan, menolak melakukan pertukaran informasi dengan negara lain yang membutuhkan informasi terhadap suatu perusahaan tertentu di negara tax haven tersebut; (4) Beberapa negara tax haven yang disebut sebagai tempat perlindungan pajak (tax shelter) atau tempat wisata pajak (Tax Resorts) memberlakukan pemajakan penghasilan terbatas pada penghasilan sumber domestik (teritorial basis taxation) atau memberikan keistimewaan pajak (tax priviledge) atas beberapa kategori penghasilan dan atau beberapa kelompok wajib pajak, dan pengawasan yang sangat longgar atas deposito dalam valuta asing yang dimiliki badan atau orang pribadi luar negeri;

Pengklasifikasian suatu negara apakah dianggap tax haven atau tidak oleh suatu negara tergantung pada definisi tax haven yang diberikan oleh negara tertentu. Masing masing negara mempunyai kebijakan tersendiri untuk menentukan negara-negara mana saja berdasarkan ketentuan perpajakan mereka yang dikategorikan sebagai negara tax haven. Sebagai contoh, Jepang dan Korea Selatan menetapkan negara yang dianggap tax havens menerapkan tarif pajak di bawah 15 persen.

\section{Ketentuan Tax Haven Country Di Indonesia dan Kriteria Tax Haven Country} Setiap Wajib Pajak Badan Dalam Negeri di Indonesia wajib melaporkan transaksinya dengan Negara tax haven 
country pada lampiran khusus 3Q-2/3B-2. Lampiran ini digunakan sebagai lampiran SPT Tahunan PPh Badan yang melaporkan nama mitra, jenis transaksi, negara mitra dan nilai transaksi, dan apakah penetapan nilai transaksi telah menggunakan prinsip kewajaran dan kelaziman usaha (arm length's principle).

Pertanyaannya adalah apakah DJP mengatur mengenai tax haven country bagi Indonesia? Di tahun 1994 dikeluarkan lampiran mengenai 32 negara yang termasuk sebagai tax haven country, lampiran Kep. Menkeu No. 650/KMK.04/1994 tgl. 12 Desember 1994 tentang penetapan saat diperolehnya dividen atas penyertaan modal pada badan usaha diluar negeri yang sahamnya tidak diperdagangkan di bursa efek. Dalam isi KMK tersebut tidak satu pasalpun yang menyebutkan mengenai tax haven country dan KMK tersebut telah dicabut dengan PMK No. 256/PMK.04/2008 dan dinyatakan tidak berlaku lagi.

UU No. 36 Tahun 2008 mengakomodasikan ketentuan tax haven country dalam Pasal 18 ayat (3c) "Penjualan atau pengalihan saham perusahaan antara (conduit company atau special purpose company) yang didirikan atau bertempat kedudukan di negara yang memberikan perlindungan pajak (tax haven country) yang mempunyai hubungan istimewa dengan badan yang didirikan atau bertempat kedudukan di Indonesia atau bentuk usaha tetap di Indonesia dapat ditetapkan sebagai penjualan atau pengalihan saham badan yang didirikan atau bertempat kedudukan di Indonesia atau bentuk usaha tetap di Indonesia."

Dalam penjelasan pasal tersebut diberikan contoh:

X Ltd. yang didirikan dan berkedudukan di negara $\mathrm{A}$, sebuah negara yang memberikan perlindungan pajak (tax haven country), memiliki 95\% (sembilan puluh lima persen) saham PT X yang didirikan dan bertempat kedudukan di Indonesia. X Ltd. ini adalah suatu perusahaan antara (conduit company) yang didirikan dan dimiliki sepenuhnya oleh
Y Co., sebuah perusahaan di negara B, dengan tujuan sebagai perusahaan antara dalam kepemilikannya atas mayoritas saham PT X. Apabila Y Co. menjual seluruh kepemilikan nya atas saham X Ltd. kepada PT Z yang merupakan Wajib Pajak dalam negeri, secara legal formal transaksi di atas merupakan pengalihan saham perusahaan luar negeri oleh Wajib Pajak luar negeri. Namun, pada hakikatnya transaksi ini merupakan pengalihan kepemilikan (saham) perseroan Wajib Pajak dalam negeri oleh Wajib Pajak luar negeri sehingga atas penghasilan dari pengalihan ini terutang Pajak Penghasilan.

Tampak jelas bahwa Pasal 18 ayat (3c) ini tidak menjelaskan lebih lanjut mengenai batasannya, kriteria maupun artikulasinya. Peraturan perpajakan di Indonesia hanya mengatur kriteria tax haven country dan hanya diatur dalam Lampiran VIII Peraturan Dirjen Pajak No. 34/PJ/2010 yang telah diubah dengan Per-19/PJ/2014, tertanggal 3 Juli 2014 hlm. 87 Huruf G tentang Pernyataan Transaksi Dalam Hubungan istimewa, Perubahan kedua atas Peraturan Dirjen Pajak No. Per-34/PJ/2010 tentang Bentuk Formulir SPT Tahunan PPh Orang Pribadi dan Badan, yaitu:

1. Negara yang mengenakan tarif pajak rendah atau negara yang tidak mengenakan pajak penghasilan; atau

2. Negara yang menerapkan kebijakan kerahasiaan bank dan tidak melakukan pertukaran informasi.

a. Negara yang mengenakan tarif rendah adalah negara yang mengenakan tarif pajak atas penghasilan lebih rendah 50 $\%$ dari tarif badan di Indonesia. (untuk tahun 2009 lebih rendah dari $14 \%$ dan untuk tahun 2010 lebih rendah dari $12,5 \%$ )

b. Negara yang menerapkan kebijakan kerahasiaan bank dan tidak melakukan pertukaran informasi adalah negara atau jurisdiksi yang berdasarkan perundang-undangannya melarang pemberian informasi nasabahnya, termasuk untuk keperluan informasi yang berkaitan dengan perpajakan. 
Chairil Anwar Pohan, Panama Papers Dan Fenomena Penyelundupan Pajak Serta Implikasinya...

Dinyatakan dalam lampiran Per19/PJ/2014 tersebut di atas, bahwa ketentuan mengenai tax haven country lebih lanjut akan diatur dalam Peraturan Menteri Keuangan. Namun sampai artikel ini dimuat belum didapatkan peraturan penetapan negaranegara yang masuk dalam kriteria tax haven country.

\section{Kegiatan Meminimalisasi Beban Pajak Melalui Tax Haven, Transfer Pricing dan Dummy Company/Letter Box Company/Reinvoicing Center}

Beberapa kegiatan yang dilakukan untuk meminimalisasi beban pajak melalui tax haven adalah sebagai berikut (Gunadi, 2007: 285):

1. Transfer pricing yang dimanfaatkan dalam membeli barang dengan harga murah/rendah (under pricing) dan menjual kembali dengan harga tinggi sehingga laba dari negara produsen dan konsumen di gerus ke tax heaven. Badan yang didirikan di tax haven tersebut sepertinya berfungsi sebagai "brass plate" company.

2. Captive insurance companies yang didirikan di tax haven sebagai perusahaan asuransi atau reasuransi seluruh anggota perusahaan grup dengan premi yang dibayar sebagai pengurang penghasilan perusahaan grup dari penghasilan.

3. Captive banking dengan memanfaatkan kemudahan dari fasilitas yang kondusif untuk pusat keuangan maka banyak cabang atau anak perusahaan perbankan yang dioperasikan di tax haven (cayman inslands). Bank demikian umumnya berfungsi sebagai pusat pencatatan (booking centre) karena transaksi nyata dilakukan di mana saja. Karena beban pajak minimal, rekayasan transaksi melewati (channeling) captive banking ini akan menguntungkan grup perusahaan.

4. Pelayaran dengan bendera tax havens. Banyak negara yang menyediakan bendera pelayaran (flag of convenience) demikian seperti Singapura, Hongkong, Malaysia, Liberia, Cyprus, Nederland Antili, Panama dan Vanuatu. Mereka membentuk perusahaan di negara dimaksud dan kepemilikan kapal diserahkan ke perusahaan tersebut.

5. Back to back loan dan paralel loan untuk menghindari ketentuan penangkal minimalisasi capital (thin capitalization). Minimalisasi potongan pajak atas bunga dan rekaraterisasi utang sebagai modal dapat dilakukan melalui rekayasa back to back loan demikian, dengan rekayasa seperti mendepositokan uang ke captive bank di tax haven dan bank tersebut meneruskan dana tersebut ke perusahaan lain anggota grup dalam bentuk pinjaman.

6. Holding companies secara meluas dimanfaatkan untuk melakukan investasi di negara berkembang. Praktek yang dilakukan ialah mendirikan dan mendanai perusahaan di tax havens kemudian perusahaan holding tersebut menanam modal (atau kadang kala memberikan pinjaman) ke perusahaan negara berkembang. Rekayasa lain ialah dengan mendirikan perusahaan antara (interposing companies atau SPV) di tax havens antara perusahaan induk di negara maju dengan perusahaan anak di negara berkembang. Perusahaan demikian sering disebut "money box" companies.

7. Perusahaan lisensi. Rekayasa minimalisasi pemajakan atas royalty dapat dilakukan dengan mendirikan perusahaan di tax havens yang mengelola harta tidak berwujud (patens, copyrights, trademarks, formulas, dan resep lainnya) yang sebetulnya milik perusahaan di negara lain.

Dalam banyak kejadian, praktik transfer pricing sangat erat kaitannya dengan dan sangat sering melibatkan tax haven country. Negara-negara yang diminati terutama merupakan negara-negara yang tidak ada Tax Treaty-nya dengan Indonesia. Transfer pricing secara umum adalah kebijakan suatu perusahaan dalam menentukan harga suatu transaksi antara pihak-pihak yang mempunyai hubungan istimewa. Hanya mereka yang memiliki hubungan istimewalah (antara perusahaan domestik dengan entitas bisnis di manca negara, atau sebaliknya, yang mampu 
merekayasa bisnis mereka dalam kerangka melakukan transfer pricing.

Beberapa waktu yang lalu kita dihebohkan dengan kasus yang menimpa Google di Inggris, Starbucks Inggris, Amazon Inggris, dan lain-lain (http://groups. yahoo.com/ neo/ groups/maksippakui2012a_pagi/ conversations/ topics/162). Starbucks Inggris misalnya, pada tahun 2011 sama sekali tidak membayar pajak korporasi padahal berhasil mencetak penjualan sebesar $£ 398$ juta. Selain itu mereka juga mengaku rugi sejak tahun 2008, dengan jumlah kerugiannya mencapai $£ 112$ juta atau sekitar Rp1,7 triliun. Padahal dalam laporan kepada investornya di Amerika Serikat, Starbucks mengatakan bahwa mereka memperoleh keuntungan yang besar di Inggris, bahkan penjualannya selama 3 tahun (2008-2010) mencapai £1,2 miliar atau sekitar Rp18 triliun. Dengan kerugian ini, Starbucks Inggris tidak pernah membayar pajak korporasi. Bahkan selama 14 tahun beroperasi di Inggris, Starbucks hanya membayar pajak sebesar £8,6 juta. Kemudian Google Inggris pada tahun 2011 juga berhasil mencatat pendapatan sebesar £398 juta tetapi hanya membayar pajak sebesar £6 juta. Hal yang sama terjadi di Amazon Inggris, di mana mereka berhasil melakukan penjualan di Inggris sebesar $£ 3,35$ miliar selama tahun 2011 tetapi hanya membayar pajak sebesar $£ 1,5$ juta.

Mengapa hal tersebut bisa terjadi? Perusahaan-perusahan multinasional tersebut menggunakan praktik transfer pricing untuk meminimalkan pembayaran pajak mereka. Caranya tidak gampang. Akan tetapi, dengan memanfaatkan celah-celah peraturan yang ada, mereka dapat memindahkan keuntungan di Inggris ke luar negeri dengan tarif pajak yang jauh lebih rendah. Walaupun terlihat legal tetapi cara-cara seperti ini dianggap sebagai cara yang amoral. Sebagaimana dikatakan oleh Margaret Hodge (anggota parlemen Inggris) ketika memanggil ketiga petinggi perusahaan tersebut, "Kami tidak menuduh Anda melanggar hukum, tapi kami menuduh Anda telah berbuat amoral," (http://www. watsonbuckle.co.uk/press_ releases/12oct_how-transfer-pricing-helpedstarbucks-minimise-their-tax-bill.php)

Hal yang sama juga terjadi di negaranegara lain termasuk di Amerika Serikat. Saat ini Amazon sedang berhadapan dengan pihak otoritas pajak Amerika Serikat (IRS) juga untuk kasus transfer pricing dengan nilai \$234 juta (http://articles.chicagotribune.com/201301-15/business/sns-rt-us-usa-taxamazonbre90e0qy-20130115_1_amazonfights-tax-court-tax-estimate).

\section{Negara-Negara Penyedia Fasilitas Keringanan Pajak OECD (Organization for Economic} Cooperation and Development) menerbitkan daftar negara penyedia fasilitas keringanan pajak sesuai kesepakatan konferensi G-20 di London yang berakhir Kamis 2/4/2009. Salah satu kesepakatan yang dicapai adalah penertiban negara-negara tax haven. G-20 mengancam memberikan sanksi tegas kepada negara yang menolak bekerja sama soal pajak. Negara itu bisa dikeluarkan dari keanggotaan Bank Dunia maupun Dana Moneter Internasional (IMF).

Secara keseluruhan, organisasi OECD yang berpusat di Paris itu menggolongkan negara dalam tiga klasifikasi, yakni : (1).Negara yang mengikuti aturan dan berbagi informasi pajak (daftar putih). (2).Negara yang menyatakan akan mengikuti aturan, namun belum melakukan apapun (daftar abuabu). (3).Negara yang belum menyetujui perubahan aturan perbankan (daftar hitam).

Beberapa negara yang diidentifikasi menjadi tax haven di antaranya Malaysia, Singapura, Filipina, Hong Kong, dan Liechtenstein. Empat negara yang masuk daftar hitam adalah Malaysia (negara bagian Labuan), Filipina, Kosta Rika, dan Uruguay. Empat negara itu dianggap tidak mau bekerja sama memberantas kejahatan pajak internasional dan menolak mengadopsi aturan baru mengenai keterbukaan perbankan dan 
finansial. Sedangkan yang masuk daftar abuabu ada 38 negara. Namun belakangan, penghapusan empat negara dari daftar hitam tersebut di atas diumumkan langsung oleh Ketua OECD pekan berikutnya setelah sebelumnya diumumkan pasca pertemuan kelompok G-20 di London. Swiss yang dikenal memiliki tradisi rahasia perbankan yang sangat ketat berjanji akan melonggarkan aturan mereka. Begitu pula, sejumlah negara yang masuk daftar abu-abu. Selain Swiss, yang masuk daftar abu-abu adalah Singapura, Brunei Darussalam, Bermuda, dan Cayman (Jawa Pos, 4 April 2009 dan Harian Seputar Indonesia, 8 April 2009).

\section{Berbagai Modus Menghindari Pajak}

Modus yang banyak dilakukan para konglomerat atau pengusaha nakal (Yunus, 2009) ${ }^{12)}$, antara lain:

1. Biasanya pengusaha nakal akan membentuk anak usaha di negara tax havens. Melalui anak usaha ini, oknum pengusaha melakukan tindakan seperti transfer pricing dan lainnya.

2. Selain itu, oknum juga menggunakan trust company, atau jasa perusahaan asing yang mengelola dana pengusaha Indonesia. Sehingga dana tersebut bisa lepas dari kewajiban pajak di Indonesia.

3. Biasanya anak usaha tersebut bergantiganti nama. Jika tidak, pengusahanya memiliki rumah tinggal di negara tax heavens agar memperoleh keringanan pajak dari status residen dia.

Ada beberapa cara bagi seseorang atau suatu perusahaan memelihara keamanan dan kenyamanan kekayaannya dengan memanfaatkan keberadaan tax havens. Menurut buku Tolley's Offshore Service (2006), antara lain ada empat cara untuk melakukannya, yakni:

1. Personal residency, yaitu dengan memindahkan domisili ke negara tax havens. Sejak abad ke-20 banyak orang kaya yang berpindah dari negara/yurisdiksi pajak yang tinggi pajaknya ke negara/yurisdiksi yang pajaknya yang rendah karena di banyak negara dasar pengenaan pajak adalah tempat tinggal wajib pajak. Para pengusaha Indonesia pun ada yang memindahkan domisili perseorangan dan perusahaannya ke Singapura atau negara lain.

2. Trading and other business activity. Banyak bisnis yang tidak memerlukan lokasi geografis tertentu atau tenaga kerja yang banyak yang didirikan di tax havens, untuk meminimalkan pembayaran pajak dengan cara transfer pricing. Mungkin ilustrasi terbaik dari ini adalah jumlah perusahaan reasuransi yang telah bermigrasi ke Bermuda selama bertahuntahun. Contoh lain termasuk layanan berbasis internet dan perusahaan grup pembiayaan. Pada 1970-an dan 1980-an banyak grup perusahaan mendirikan perusahaan lokal atau special purpose vehicle company (SPV) sebagai entitas offshore untuk tujuan "reinvoicing". Perusahaan-perusahaan reinvoicing ini hanya membuat/mendapat margin tanpa melakukan apapun fungsi ekonomi, sehingga memungkinkan grup perusahaan tersebut melakukan "skim" keuntungan dari yurisdiksi pajak yang tinggi.

3. Asset holding, yaitu dengan memanfaatkan offshore trust atau offshore company atau kepemilikan trust dari suatu perusahaan untuk mengelola kekayaannya di luar negeri. Perusahaan atau trust didirikan dalam satu tax havens, dan biasanya akan diadministrasikan dan residen-nya di tempat lain. Fungsinya adalah untuk menguasai aset (asset holding) yang dapat terdiri dari portofolio investasi di bawah penguasaan manajemen, perusahaan perdagangan atau kelompok, aset fisik seperti real estate atau barang bergerak yang berharga. Inti dari pengaturan tersebut adalah bahwa dengan mengubah kepemilikan aset menjadi entitas yang bukan tax resident di wilayah/yurisdiksi hukum pajak yang tinggi (the high-tax jurisdiction) mereka tidak dikenakan pajak di wilayah/yurisdiksi hukum itu. Misalnya yang dilakukan oleh salah satu tersangka kasus Bank Century. 
4. Financial intermediary. Sebagian besar kegiatan ekonomi di tax havens saat ini terdiri dari jasa keuangan profesional seperti reksa dana, perbankan, asuransi jiwa dan dana pensiun. Umumnya dana disimpan dengan perantara di yurisdiksi pajak rendah, dan perantara kemudian meminjamkan atau menginvestasikan uang (sering kembali ke yurisdiksi pajak yang tinggi). Jadi, dana yang dihimpun di negara/yurisdiksi pajak yang rendah kemudian disalurkan ke berbagai negara yang pajaknya lebih tinggi. Hal ini berhasil dilakukan Cayman Island, wilayah kecil dengan penduduk tidak lebih dari 60.000 orang, tetapi memiliki sekitar 350 offshore bank. Cara ini sarat dengan pencucian uang dan penggelapan pajak. Biasanya pertukaran informasi terkait dengan tindak pidana pencucian uang yang berasal dari tindak pidana perpajakan sangat sulit dilakukan. Mengingat beberapa ciri negara tax havens sebagaimana disebutkan di atas, negara tax havens biasanya juga dimanfaatkan oleh pelaku tindak pidana untuk melakukan pencucian uang.

Beberapa langkah yang dilakukan oleh pemerintah Indonesia untuk menanggulangi pelaku-pelaku pengemplang pajak di negaranegara tax havens, seperti:

1. Indonesia memiliki kesepakatan mutual legal assistence (MLA) dengan Singapura. Akan tetapi, kesepakatan tersebut tidak berlaku surut, sehingga untuk dana-dana yang sudah lama mengendap di sana tidak bisa ditarik lagi.

2. Pusat Pelaporan dan Analisis Transaksi Keuangan(PPATK) telah memiliki hubungan erat dengan negara-negara tersebut. Akan tetapi, hubungan ini hanya sebatas tukar menukar informasi. Sedangkan, untuk langkah aksinya pihak Departemen Luar Negeri atau Kepolisianlah yang harus menjalin hubungan sendiri dengan otoritas tax havens.

3. Untuk penelitian atau analisis transaksi keuangan, PPATK sudah tergabung dengan kelompok Egmont, sehingga,
PPATK memiliki akses ke negara-negara tax havens seperti pada kasus Robert Tantular di Jersey Island. Dalam kasus itu, PPATK bisa memperoleh informasi rekening Robert. Selanjutnya, Kepolisian dan Kejaksaan meminta permohonan pemblokiran, sehingga rekening dan aset tersangka kasus Bank Century dan Antaboga senilai US\$16,5 juta bisa diblokir.

\section{Tax Haven Mematikan Negara-Negara Berkembang}

Diungkapkan oleh Slemrod dan Wilson dalam jurnal Dhammika Dharmapala (2008) yang berjudul "What Problem and Opportunities are Created by Tax Haven?", bahwa tax haven mengikis basis pajak high tax countries karena perusahaan multinasional dapat menggunakan tax haven untuk mengurangi atau menunda kewajiban pajak ke negara-negara lain melalui pengaturan strategies harga transfer dan penggunaan strategi utang antarafliasi. Bagi negara seperti Indonesia, tax haven merupakan sistem berbahaya dan mematikan, dengan beberapa alasan sebagai berikut : (1). Tax haven memberikan fasilitas tariff pajak yang rendah bahkan nol dan kerahasiaan informasi yang sangat ketat. (2). Tax haven memicu wajib pajak berusaha membuat skema tertentu untuk memaksimalkan keuntungan. (3). Tax haven juga menjadi muara bagi aliran uang illegal perusahaan multinasional yang beroperasi di negara-negara dengan tarif pajak yang tinggi.

Beberapa alasan mengapa Tax Haven tersebut berbahaya dan merugikan negara berkembang:

1. Tax haven lebih banyak merugikan negara berkembang karena banyak perusahaan multinasional memanfaatkan tax haven untuk penggelapan pajak. Banyak perusahaan multinasional yang antusias untuk memindahkan asset keuangan dan mendirikan perusahaan-perusahaan ke negara tax haven karena tax haven menerapkan tarif pajak yang rendah dan beberapa negara tax haven malah tidak 
Chairil Anwar Pohan, Panama Papers Dan Fenomena Penyelundupan Pajak Serta Implikasinya...

ada pajak sama sekali. Apalagi kerahasiaan informasi yang dimilki tax haven memungkinkan wajib pajak tidak melaporkan kekayaan atau penghasilan secara keseluruhan sehingga pajak yang dikenakan dapat diminimalkan (Yanuar Falak Abiyunus, 2013). Dapat dikatakan hal ini menghambat perkembangan ekonomi, pengentasan kemiskinan dan penyediaan public goods di negara berkembang. Di Indonesia, hampir $75 \%$ APBN Indonesia disokong oleh pendapatan dari sektor pajak, sehingga jika Indonesia turut menurunkan tariff pajak, maka pendapatan negara akan berkurang. Di samping itu, jumlah penduduk di Indonesia sangat banyak dibanding tax haven yang penduduknya sedikit, akan sangat sulit menghidupi warga negara dengan pendapatan negara yang kecil. Berkaitan dengan kerahasian informasi, di Indonesia diwujudkan dalam bentuk bank sebagai tempat penyimpanan asset keuangan warga negara termasuk perusahaan-perusahaan yang beroperasi di Indonesia. Undang-undang di Indonesia mengamanatkan adanya keterbukaan informasi untuk kepentingan perpajakan, penyelesaian piutang bank yang sudah diserahkan kepada Badan Urusan Piutang dan Lelang Negara /Panitia Urusan Piutang Negara, dan untuk kepentingan peradilan dalam perkara pidana (Pasal 40 ayat 1 , pasal 41 ayat 1 , dan pasal 42 ayat 1 UU No. 10 tahun 1998 tentang Perbankan). Tidak seperti di tax haven,

PT. Asian Agri telah melakukan rekayasa keuangan internasional dengan merekayasa penjualan.

"Penjualan dilakukan melalui ekspor yang pengiriman barangnya langsung ditujukan ke negara pembeli (end buyer) tetapi dokumen keuangan yang berkaitan dengan transaksi ekspor tersebut (L/C) , Invoice) dibuat seolah-oleh dijual kepada perusahaan di Hong Kong (Twin Bonus Ediblle Oils Ltd., Goiod Fortune Oils\&Fats Ltd., United Oils\&Fats Ltd., atau Ever Resources Oils\&Fats), kemudian dijual lagi ke perusahaan di macau (Global Advance Oils\&fats Ltd) untuk keadaan tertentu kerahasian informasi di Indonesia dapat bersifat fleksible demi kepentingan negara, sehingga keberadaan tax haven menjadi ancaman yang dapat merugikan Indonesia.

2. Fasilitas-fasilitas yang ditawarkan tax haven menjadi pilihan menarik bagi perusahaan multinasional untuk membuat skema-skema tertentu seperti tax planning. Skema tersebut digunakan untuk memaksimalkan. Dengan skema tax planning, penghasilan yang diperoleh perusahaan multinasional sebagai wajib pajak di stuatu negara dapat dipindahkan ke negara tax haven. Hal ini tentu saja mengakibatkan berkurangnya dasar pemajakan negara domisili WP (pajak yang dibayarkan kecil), padahal WP tersebut memperoleh penghasilan dengan memanfaatkan segala fasilitas publik yang diberikan di negara domisili (free rider). Tax planning agresif akan sangat merugikan negara dan tergolong unacceptable tax avoidance.

Contoh perusahaan di Indonesia adalah PT Asian Agri (AAG). PT. Asian Agri dinyatakan bertanggung jawab atas pelaporan pajak di beberapa kantor pajak. Disebutkan adanya tax planning meeting yang membahas perencanaan untuk mengecilkan pajak" (Putusan Mahkamah Agung No. 2239 K/PID.SUS/2012). Jelas sekali, aktivitas tersebut merugikan negara Indonesia sebagai tempat beroperasinya PT. Asian Agri.

atau British virgin Island/BVI) (Asian Agri Abadi Oils\&Fats Ltd.) baru selanjutnya dijual ke End Buyer. Padahal perusahaan di Hongkong, Macau maupun di BVI adalah perusahaan paper company atau Special Purpose Vehicle) (SP yang digunakan sebagai fasilitator)".

Secara dokumentasi SPV mendukung transaksi tersebut dan sebagai tempat untuk menampung selisih harga jual. "Rekayasa penjualan produk-produk AAG ke luar negeri tersebut dimaksudkan untuk mengubah harga jual yang seharusnya ke end buyer diganti dengan harga yang lebih rendah ke perusahaan-perusahaan tersebut 
di Hong Kong, sehingga keuntungan menjadi lebih rendah untuk perusahaan di Indonesia"

(Putusan Mahkamah Agung No, 2239 K/PID.SUS/2012).

Lebih jauh lagi dengan memanfaatkan kerahasiaan tax haven ditambah skema tax planning, tax haven menjadi muara bagi aliran dana illegal, seperti dana dari aktivitas kriminal, black market dan korupsi. Dana-dana ini mengalir bebas dan aman tanpa terdeteksi oleh otoritas yang berwenang. Kemudahan pendirian perusahaan dengan tidak adanya transparansi legalisasi dan tidak adanya persyaratan subtansi ekonomi dalam pendirian perusahaan "perusahaan dapat didirikan untuk mendapatkan manfaat pajak saja tanpa benar-benar memiliki kegiatan bisnis"(Yanuar Falak Abiyunus, 2013). Ditambah dengan adanya aturan kerahasiaan informasi, sulit

\section{Contoh Kasus Lain Terkait Tax Haven Country}

Kasus Indofood merupakan kasus
No.03/2005/2497 yang diputuskan pada tingkat Mahkamah Agung di Inggeris, yaitu The Supreme Court of Judicature Court of Appeal (Civil Division) antara penuntut Indofood International Finance yang berkedudukan di Mauritus dan terdakwa JP Morgan Chase Bank N.A. cabang Inggeris sebagai trustee di Pengadilan Inggeris. Terkait kasus ini, terdapat beberapa perusahaan dari beberapa Negara yang digunakan, yaitu (1).PT. Indofood Sukses Makmur, Tbk selanjutnya disebut ISM, yang berada di Indonesia;(2).Indofood International Finance Ltd selanjutnya disebut IIF, yang berada di Mauritus; (3).Newco yang berada di Belanda; (4).JP Morgan Chase Bank NA cabang Inggeris, yang selanjutnya disebut JPM, yang berada di Inggeris.

Pada tahun 2002, group Indofood melalui ISM di Indonesia ingin meningkatkan keuangannya melalui penerbitan obligasi Internasional. Hal ini dilakukan dengan menggunakan IIF di Mauritus sebagai special
Itulah mengapa PT AAG membayar pajak di Indonesia kecil yang sangat merugikan Indonesia.

mengidentifikasi siapa sebenarnya pemilik perusahaan yang didirikan di sana sehingga banyak sekali aliran dana-dana yang illegal. PT. Asian Agri menjadi salah satu contoh perusahaan yang melakukan hal ini. Perusahaan ini dinilai melakukan penggelapan pajak. "Selain itu, jika mengacu pada UU No. 8 tahun 2010 tentang Pencegahan dan Pemberantasan Tindak Pidana Korupsi), kejahatan semacam ini merupakan salah satu predictive crimes dari tindak pidana pencucian uang." (Rio Ismail, 2014). Uang yang seharusnya masuk sebagai pendapatan negara Indonesia justru dilarikan ke luar negeri dalam rangka kegiatan memperkaya diri sendiri atau perusahaan.

purpose vehicle. Apabila ISM melakukannya sendiri, ia berkewajiban membayar Pajak Penghasilan sebagai $20 \%$ atas kewajiban pemotongan pajak atau pembayaran bunga. Jumlah tariff ini dapat dipotong menjadi $10 \%$ apabila obligasi yang diterbitkan oleh anak perusahaannya yang dimiliki secra penuh, yaitu menggunakan IIF yang didirikan di Mauritus sehingga transaksi ini tunduk pada Treaty antara Indonesia dan Mauritus.

Pada 18 Juni 2002, IIF menerbitkan obligasi senilai US\$280.000.000,00 dengan bunga sebesar $10,375 \%$. Seluruh hasil dari emisi obligasi dipinjamkan kepada ISM dengan perjanjian utang yang sama rancangan pinjamannya dengan rancangan obligasi yang diterbitkan oleh IIF. Tingkat bunga yang harus dibayarkan juga sama yaitu 10,375\% (neto) per tahun yang harus dibayarkan oleh ISM kepada IIF setiap 6 bulan.

Penerbitan, pelayanan dan penebusan obligasi, dan pinjaman kepada induk penjamin diatur oleh kondisi yang disyaratkan dalam Loan Notes, yaitu apabila terdapat 
Chairil Anwar Pohan, Panama Papers Dan Fenomena Penyelundupan Pajak Serta Implikasinya...

perubahan peraturan perpajakan baik di Mauritus maupun di Indonesia yang tidak dapat dihindari serta mengakibatkan tambahan jumlah PPh atas pembayaran bunga melebihi $10 \%$, IIF berhak melunasi seluruh obligasi yang masih terutang dengan nilai par value sebelum jatuh tempo, yaitu sebelum 18 Juni 2007.

Pada 24 Juni 2004, pemerintah RI mengumumkan akan menterminasi/mengakhiri Treaty dengan Mauritus efektif sejak tanggal 1 Januari 2005. Salah satu konsekuensi adalah bahwa sejak 1 Januari 2005, jumlah $\mathrm{PPh}$ atas pembayaran bunga dari ISM kepada IIF akan meningkat dari semula $10 \%$ menjadi $20 \%$. Hal ini menimbulkan polemik dan berbagai skema restrukturisasi pembiayaan agar pengenaan PPh sebesar $20 \%$ dapat dihindari.

Pada 20 Agustus 2004, penerbit obligasi menyampaikan pemberitahuan kepada wali amanat (trustee) mengenai keinginannya untuk melunasi seluruh obligasi. Penerbit menegaskan tidak ada jalan keluar untuk menghindari kewajiban memotong $\mathrm{PPh}$ sebesar $20 \%$.

Pada 18 November 2004, penerbit mengirimkan draft pemberitahuan pelunasan kepada trustee untuk meminta persetujuannya agar pelunasan dapat dilakukan tanggal 29 Desember 2004.

JPM sebagai trustee menolak proposal dari penerbit obligasi karena meyakini ada jalan keluar atau skema pembiayaan lain untuk menghindari pemotongan $\mathrm{PPh}$ atas bunga tersebut. Salah satu skema yang ditawarkan adalah mendirikan sebuah perusahaan baru (interposing company), yaitu Newco

Sejumlah negara di dunia memberikan skema tarif pajak rendah bahkan sampai 0 persen dengan tujuan untuk menarik perusahaan-perusahaan asing menginvestasikan atau menyimpan dananya di negara tersebut. Menurut Taxhaven.org, terdapat beberapa negara yang termasuk Tax Haven Countries, antara lain: Andorra, Antigua and Barbuda, the Bahamas, Cayman Islands, Costa Rica, British Virgin Islands, Isle of Man, Guernsey, Samoa, Bermuda, Cyprus, Gibraltar, Dominica, Belize, Hongkong, Singapura, dan Vanuatu. berdasarkan hukum di yurisdiksi Belanda yang sudah memiliki Treaty dengan Indonesia dan menempatkannya di antara ISM dan IIF sehingga dapat menikmati tariff pemotongan $\mathrm{PPh}$ sesuai Treaty, yaitu maksimal $10 \%$.

Berdasarkan skema pembiayan yang diusulkan dari trustee tersebut, ISM berkonsultasi dengan pihak Ditjen Pajak Indonesia untuk menanyakan apakah perusahaan baru tersebut dapat disebut sebagai beneficial owner.

Jawaban berupa Surat Direktur Jenderal Pajak tertanggal 24 Juni 2005 menyatakan bahwa perusahaan baru tersebut merupakan conduit company dan nominee yang bukan merupakan pemilik yang sebenarnya dari penghasilan atau bukan beneficial owner.

Pihak mahkamah Agung Inggeris ikut mempertimbangkan surat dari Dirjen pajak Indonesia. Selain itu, dapat dilihat dalam skema baru siapa sebenarnya pihak yang menerima penghasilan. Atas tiap transaksi yang dilakukan, akta pendirian perusahaan, ataupun kontrak dapat diyakini apakah Newco sebagai penerima penghasilan adalah benefial owner atau bukan. Kontrak mewajibkan Newco terikat dengan skema, yaitu ISM (parent) yang sebenarnya membayar buga pinjaman kepada penerbit obligasi melalui Newco.

Akhirnya pengadilan Inggeris menolak status beneficial owner terhadap usulan JPM untuk membentuk Newco sebagai perusahaan baru atau interposing company tersebut. (Sumber: Hendharto Oetomo, et all, dalam buku "Tax Treaty is Easy, undated, hlm.136-139)

Kebanyakan negara-negara tersebut merupakan negara kepulauan kecil sehingga sering juga dijuluki sebagai offshore financial centres karena keberadaannya yang jauh di tengah lautan. Meskipun demikian, tidak sedikit pula negara daratan yang dikategorikan tax haven countries seperti Swiss, Monaco, Panama, dan sebagainya.

Menurut businessdictionary.com offshore financial centres adalah "Place such as Anguilla, Antigua, Bahamas, Bahrain, Cayman Islands, Hong Kong, Isle of Man, Jersey, Lebanon, Luxembourg, Netherlands 
Antilles, Panama, Singapore, and United Arab Emirates (UAE) which offers little or no government interference in legitimate business and financial activities. In many cases, OFCs also offer very low or zero tax rates, and provide excellent communications facilities. Also called international financial center (IFC)." http://www.businessdictionary.com/definition /offshore-financial-center-OFC.html

Swiss adalah salah satu negara yang selama ini dikenal sebagai surga menyimpan uang. Para nasabah kakap-entah itu orang kaya atau koruptor berbondong-bondong menyimpan uang mereka di perbankan. Pemerintah dan otoritas moneter Swiss melarang bank dan karyawannya membocorkan data nasabah. Bila aturan ini dilanggar, hukumannya amat berat. Selain Swiss, ada Liechtenstein. Negara mungil yang berada di Pegunungan Alpen ini menjadi tempat yang sangat menarik bagi para konglomerat menyimpan uang. Seperti halnya Swiss, sistem perbankan yang dianut di Liechtenstein sangat mengagungkan kerahasiaan data nasabah.

Belakangan, Singapura menjadi daya tarik sendiri. Negeri jiran ini kerap dijadikan surga bagi para 'miliader hitam' untuk menyimpan uang. Baru-baru ini $C N B C$ melaporkan, orang-orang kaya Jerman telah menarik uang mereka dalam jumlah miliaran dolar AS dari Swiss untuk disimpan di Singapura. Alasannya, pajak yang lebih rendah ketimbang di Swiss. (Satrio AN, Indonesian review.com)

\section{Pemanfaatan Pajak Untuk Mengurangi Penduduk Miskin}

Sejak beberapa tahun terakhir, kasuskasus tindak pidana di bidang perpajakan selain kasus Asian Agri sebenarnya cukup banyak. Perhatian masyarakat yang sangat besar kepada Asian Agri tentu wajar karena besarnya dugaan kerugian negara senilai $\mathrm{Rpl}, 3$ triliun. Saat negara membutuhkan pajak untuk melanjutkan pembangunan, kesadaran dan kepatuhan seluruh masyarakat untuk membayar pajak tampaknya sudah harus segera diwujudkan. Siapa pun tentu tidak ingin dikatakan sebagai penumpang gelap (free rider) karena tidak mau bayar pajak. Begitu juga, orang tidak mau dikatakan sebagai pengemplang pajak dan pelaku penggelapan pajak karena membayar pajak tidak benar. Pajak adalah salah satu sumber penerimaan negara, dan itu telah menjadi kesepakatan bersama. Bahkan sejak sektor migas tidak lagi dapat diharapkan sebagai motor pembangunan RI, maka pajak saat ini menjadi satu-satunya sumber penerimaan terbesar pembangunan bangsa, untuk kesejahteraan bangsa. Pajak tidak bisa dihindarkan lagi dalam kehidupan setiap individu, dan semua anak bangsa harus menyikapinya dengan benar. Pajak tidak boleh dianggap sebagai momok, tetapi sebaliknya harus diperlakukan sebagai wujud rasa terima kasih kita kepada negeri ini. Bisa dikatakan bahwa para pengemplang pajak (termasuk pelaku penggelapan pajak) adalah kelompok orang yang tidak mencintai negeri ini. Mereka tidak mampu menyediakan fasilitas umum untuk kebutuhan atau keperluannya sendiri-sendiri. Bisanya mereka hanya mengklaim haknya sebagai warga negara, namun ketika negara meminta mereka melaksanakan kewajiban perpajakannya dengan benar, banyak alasan untuk menghindari pajak, hanya ingin menikmati fasilitas umum negara, tetapi tidak mau turut berkontribusi dalam membayar pajak untuk berpartisipasi dalam membangun bangsa. Penghasilan yang diperolehnya bisa terwujud karena adanya fasilitas umum yang disediakan negara yang mereka nikmati dengan biaya yang sangat murah bahkan banyak pula yang gratis. Awalnya mereka mendudukkan dirinya sebagai "penumpang gelap" tetapi karena keenakan menikmatinya sehingga meningkat atributnya menjadi pengemplang pajak dan pelaku penggelapan pajak, inilah indikasi mereka menggagalkan upaya negara untuk menyejahterakan rakyat.

Coba kita lihat penduduk miskin masih cukup banyak di negeri ini. Badan Pusat Statistik (BPS) mencatat, jumlah penduduk miskin Indonesia per Maret 2016 
sebanyak 28,01 juta jiwa atau 10,86 persen dari total penduduk Indonesia. Itu artinya, jumlah penduduk miskin di Indonesia bertambah dibandingkan per Sep 2014 sebanyak 27,73 juta jiwa.(http://www.cnnindonesia.com/ekonomi/ 20160104131350-78-102009/) Lalu pertanyaannya, apa hubungannya penduduk miskin dengan pengemplang pajak (termasuk pelaku penggelapan pajak)? Seandainya negeri ini tidak ada pengemplang pajak (termasuk pelaku penggelapan pajak), secara tidak langsung mau tidak mau kesejahteraan masyarakat miskin akan meningkat, atau jumlah penduduk miskin akan berkurang. Sekarang ini belum ada instrumen lain selain pajak yang bisa menjadikan penduduk miskin berkurang. Bahkan Pasal 34 Ayat (1) UUD 45 secara tegas menyebutkan bahwa negara wajib melindungi fakir miskin dan orang telantar. Nah, untuk melindungi fakir miskin dan anak telantar supaya mereka bisa hidup lebih baik, mereka harus sekolah serta mendapat makan atau pekerjaan yang baik.

Penambahan jumlah penduduk miskin juga bisa dikatakan seakan diciptakan oleh pengemplang pajak (termasuk pelaku penggelapan pajak). Bahkan secara ekstrim, pengemplang pajak tersebut punya andil dalam memiskinkan masyarakat. Tidak bisa dipungkiri sebenarnya para pengemplang pajak (termasuk pelaku penggelapan pajak) sudah menggerogoti atau menggagalkan upaya negara untuk menyejahterakan rakyat. Wajar kiranya menggelar tindakan hukum berupa pemeriksaan, penyidikan, dan penyanderaan merupakan instrumen lain dari hukum pajak yang bisa digunakan untuk menindak pengemplang pajak (termasuk pelaku penggelapan pajak). Dengan demikian, semua masyarakat hendaknya mendukung tugas penerimaan pajak ini dengan menyadarkan para pengemplang pajak (termasuk pelaku penggelapan pajak) agar negara yang kita cintai dapat terus berlangsung. Hanya dengan instrumen pajaklah penduduk miskin bisa berkurang.

Last but not least, daripada kita terperangkap dengan jebakan utang akibat kurangnya penerimaan pemerintah dari potensi pajak yang tidak bisa terealisir, maka untuk mengkompensasi kerugian pemerintah yang disebabkan oleh adanya penyelundupan pajak tersebut, pengefektifan intensifikasi dan ekstensifikasi pemungutan pajak harus secara optimal diporioritaskan membidik pada dua hal, yakni; kesatu pada WPOP besar yang selama ini tingkat kepatuhannya rendah dalam membayar pajak, dan kedua juga tidak kalah pentingnya menyasar pada sektor UMKM yang selama ini sangat banyak terabaikan, keduanya menjadi pilihan yang tak terelakkan. Basis penerimaan pajak secara fundamental harus diperluas, proses pembinaan dan pengawasan dari fiskus yang plan of action-nya secara gradual dilakukan mulai dari secara persuasi hingga pengenaan sanksi yang tegas. Sudah berjalan 33 tahun sejak reformasi perpajakan Indonesia pertama diluncurkan dengan lahirnya UU KUP, UU $\mathrm{PPh}$ dan UU PPN serta UU PDRD dan kemudian diikuti dengan proses pembelajaran PP 46/2003 hingga kini yang notabene sudah berlangsung tiga tahun yang kemudian diperkuat lagi dengan UU Pengampunan Pajak tahun 2016, dengan rule of the gamenya sudah cukup untuk menegakkan hukum pajak (law enforcement) agar pengenaan pajak ini bisa dilaksanakan secara "merata" kepada segenap warga negara Indonesia yang memiliki penghasilan yang dikenakan pajak. Keadilan pajak baik secara horizontal dan vertikal dengan landasan asas equality harus ditegakkan dan bekerja secara fungsional, dan tidak ada warga negara Indonesia yang kebal pajak, semuanya terbebani pajak (sesuai ukurannya) karena semua orang juga sudah menikmati benefit dari pajak itu sendiri.

\section{Penutup}

1. Kita perlu memagari negeri ini dengan membuat peraturan tentang kriteria tax haven country dan penetapan daftar tax haven country sebagai tindak lanjut dari Peraturan Menkeu No. 19/PJ/2014, sehingga terdapat kepastian hukum dalam dasar hukumnya yang jelas terutama ketika kasus-kasus perpajakan internasional yang terkait dengan tax haven country dan transfer pricing di persidangan peradilan pajak atau peradilan umum/negeri. 
2. Pengemplang pajak (termasuk pelaku penggelapan pajak) harus diberi aturan tindakan hukum yang tegas bila kita menginginkan kesejahteraan masyarakat miskin meningkat, atau jumlah penduduk miskin berkurang. Praktik pengemplangan pajak selama ini marak dilakukan oleh pebisnis-pebisnis wajib pajak orang pribadi hingga para konglomerat didominir penyebabnya karena aturan tindakan hukum yang masih lemah dalam penegakannya, bahkan oknum penegak hukumnya sendiri banyak bermain di ranah pajak untuk kepentingan pribadinya sehingga penerimaan negara menjadi terganggu. Oleh sebab itu UU Tax Amnesty sebagai suatu cara untuk membidik pelaku-pelaku bisnis yang selama ini memparkir dananya di tax haven countries agar pulang ke tanah air kita yang tercinta ini menjadi suatu keniscayaan, setiap warga negara harus mendukung program tax amnesty ini agar supaya target penerimaan pajaknya bisa terbidik dengan sukses.

3. Untuk meng-offset hilangnya potensi penerimaan pajak dari para pengemplang pajak (termasuk pelaku penggelapan pajak) di dalam dan luar negeri, maka basis penerimaan pajak secara fundamental harus diperluas dan diintensifkan, dengan mengoptimalkan pemungutan pajak di tataran WPOP besar dan sektor pelaku bisnis UMKM.

\section{Daftar Kepustakaan}

Barnes, William Spraque (Director), Taxation In The United States. Commerce Clearing House, Harvard University World Tax Series, Chicago, 1963.

Bracewell. Milnes Barry. The Economics of International Tax Avoidance, Political Power vs Economics Law, Number 4 in International Series of The Rotterdam Institute For

Fiscal Studies : Kluwer, Deventer, Erasmus University, 1980.
Bjorn Westberg. Cross Border Taxation of Commerce:Amsterdam, International Bureau of

Fiscal Documentation, 2002. Bracewell. Milnes Barry. The Economics of International Tax Avoidance, Political Power vs Economics Law, Number 4 in International Series of The Rotterdam Institute For Fiscal Studies : Kluwer, Deventer, Erasmus University, 1980.

Brian J. Arnold dan Michaele J. McIntyre. International Tax Primer: Kluwer Law International, Den Haag, 1995.

Crumbley, D. Larry, Jack P. Friedman, dan Susan B.Andrers. Dictionary of text terms. 1994.

Darussalam dan Danny Septriadi. Konsep dan Aplikasi Cross Border Transfer Pricing

Untuk Tujuan Perpajakan : Danny Darussalam Tax Center, Jakarta, 2008.

Knechtle. Arnold.A. Basic Problems In International Fiscal Law : Kluwer, Deventer, 1979

Kurniawan, Anang Mury. Pajak Internasional Beserta Contoh Aplikasinya: Ghalia Indonesia, Bogor, 2011 Tax Treaty Memahami P3B

Melalui Studi Kasus: Bee Media Indonesia, Jakarta, 2012.

Gunadi. Pajak Internasional. Edisi Revisi 2007: Lembaga Penerbit FEUI, Jakarta, 2007.

OECD. Harmful Tax Competition, An Emerging Global Issue, France, 1998 Oetomo, Hendharto, et all. Tax Treaty is Easy:PPM Manajemen

Jennifer Blouin, et al. Thin Capitalization Rules and Multinational Firm Capital Structure.

IMF Working Paper (C2014 InternationalMonetary Fund WP/14/12) Larry D, Jack P. Friedman, Susan B. Anders. Dictionary of Tax Terms: Barron's, 1994.

Pohan, Chairil Anwar. Manajemen

Perpajakan-Strategi Perencanaan Pajak dan Bisnis,

edisi 4-Revisi: PT.Gramedia Pustaka Utama, Jakarta, 2012. 
Chairil Anwar Pohan, Panama Papers Dan Fenomena Penyelundupan Pajak Serta Implikasinya...

. Konsep dan Aplikasi Perpajakan

Indonesia, Teori dan Kasus : Bumi Aksara, Jakarta, 2014.

Read Colin and Greg N.Gregoriou(editor). International Taxation Handbook :CIMA, USA, 2007.

Rohatgi, R. Basic International Taxation : Kluwer Law International, Hague, 2002

Simanjuntak,Timbul Hamongan dan Imam Mukhlis. Dimensi Ekonomi Perpajakan Dalam

Pembangunan Ekonomi : Penerbit Raih Asa Sukses, Depok, 2012

\section{Jurnal dan Sumber lain:}

1) Tribunjateng.com, 5 April 2016)

2) Jurnal BPPK, Vol. No. 1, 2014:14).

3) Kompas, 5 April 2009

4) \& 6) Media Indonesia, 1 Mei 2009

5) DannyDarussalam.com Tax Center, 15/4/09

7) http://dannydarussalam.com/insights/pana ma-papers-perencanaan-pajakpenghindaran-pajak-ataukahpenggelapan-pajak-2

8) http://groups. yahoo.com/neo/ groups/maksippakui2012a_pagi/ conversations/ topics/162

9) http://www. watsonbuckle.co. uk/press releases/12oct_how-transfer-pricinghelped-starbucks-minimise-their-taxbill.php
10) http://articles.chicagotribune.com/201301-15/business/sns-rt-us-usa-taxamazonbre90e0qy-20130115_1_amazonfights-tax-court-tax-estimate

11) Jawa Pos, 4 April 2009 dan Harian Seputar Indonesia, 8 April 2009

12) Yunus, Pusat Pelaporan dan Analisis Transaksi Keuangan (PPATK), Media Indonesia, 29 April 2009

13) Satrio AN, Indonesian review.com

14) http://www.cnnindonesia.com/ekonomi/2 0160104131350-78-102009/

15) Taxhaven.org

Dharmapala, Dhammika . What problems and opportunities are created by tax havens? oxford journals . Oxford Review of Economic Policy. Volume 24, Issue 4 http://oxrep.oxfordjournals.org/conten t/24/4/661.short

\section{Peraturan Perundang-undangan}

Republik Indonesia. "Undang-Undang Nomor 7 Tahun 1983 tentang Pajak Penghasilan sebagaimana telah beberapa kali diubah terakhir dengan Undang- Undang No. 36 Tahun 2008".

Putusan Mahkamah Agung No. 2239 K/PID.SUS/2012

Peraturan Menkeu No. 19/PJ/2014

Peraturan Dirjen Pajak No. 34/PJ/2010 yang telah diubah dengan Per-19/PJ/2014 